\title{
Penurunan Konsentrasi COD Limbah Batik Pada Proses Seeding dan Aklimatisasi Menggunakan Material Preservasi Mikroorganisme (MPMO)
}

\author{
Veny Rachmawati, Ratih Nurjayati*, Mutia Dewi Yuniati \\ Pusat Penelitian Geoteknologi, Lembaga Ilmu Pengetahuan Indonesia, Kota Bandung, Jawa Barat 40135, Indonesia \\ *Corresponding author: rnurjayati@gmail.com
}

Info Artikel:Diterima 5 April 2021 ; Direvisi 4 Januari 2022 ; Disetujui 4 Januari 2022

Tersedia online : 10 Februari 2022 ; Diterbitkan secara teratur : Februari 2022

Cara sitasi (Vancouver): Rachmawati V, Nurjayati R, Yuniati MD. Penurunan Konsentrasi COD Limbah Batik Pada Proses Seeding dan Aklimatisasi Menggunakan Material Preservasi Mikroorganisme (MPMO). Jurnal Kesehatan Lingkungan Indonesia [Online]. 2022 Feb;21(1):73-82. https://doi.org/10.14710/jkli.21.1.73-82.

\begin{abstract}
ABSTRAK
Latar belakang: Batik merupakan warisan budaya Indonesia yang nilai ekspornya meningkat pesat. Dampak ini dapat meningkatkan pendapatan negara secara signifikan. Di sisi lain, memperluas kesempatan kerja bagi masyarakat untuk memproduksi batik. Namun, produksi batik yang besar meningkatkan volume limbah. Permasalahan ini dapat mencemari lingkungan jika limbah batik tidak terurai dengan baik. Oleh karena itu, kami mengusulkan metode bioremediasi untuk menguraikan polutan COD dalam limbah batik. Penelitian ini bertujuan untuk mengukur kemampuan MPMO dalam mereduksi COD pada limbah batik. Hasil penelitian terdahulu menunjukkan bakteri Bacillus licheniformis memiliki kemampuan mereduksi COD pada limbah tekstil. Selain itu, MPMO yang mengandung bakteri Bacillus licheniformis juga terbukti dapat menurunkan nilai COD pada IPAL industri gula.

Metode: Penelitian ini dilakukan dalam skala laboratorium, dan menggunakan sistem batch untuk proses seeding dan aklimatisasi pada MPMO. Pada proses seeding menggunakan nutrien buatan untuk menumbuhkan mikroorganisme. Proses aklimatisasi menggunakan \% v/v campuran limbah batik dan nutrien buatan sebagai proses adaptasi mikroorganisme terhadap limbah. Parameter selama proses seeding dan aklimatisasi yaitu COD, pH, MLSS, dan MLVSS. Pengambilan parameter COD dilakukan setiap 0 jam pada influen dan 24 jam pada efluen reaktor.

Hasil: Nilai $\mathrm{COD}_{\text {influen }}, \mathrm{COD}_{\text {efluen, }}$ Efisiensi penyisihan COD, $\mathrm{pH}_{\mathrm{awal}}, \mathrm{pH}_{\mathrm{akhir}}, \mathrm{MLSS}$, dan MLVSS yang diperoleh selama proses aklimatisasi masing-masing antara $1145-3084 \mathrm{mg} / \mathrm{L}, 354-1268 \mathrm{mg} / \mathrm{L}, 54-82 \%, 6.43-8.25$, 7.33$8.32,790.5-2356.5 \mathrm{mg} / \mathrm{L}, 0.454-1.657 \mathrm{mg} / \mathrm{L}$.

Simpulan: Penggunaan MPMO dengan bakteri Bacillus licheniformis dapat menyisihkan COD limbah batik pada proses aklimatisasi sebesar $82 \%$ dengan nilai rata-rata efisiensi penyisihan COD sebesar $65 \%$.

Kata kunci: Limbah batik; MPMO; Bacillus licheniformis; bioremediasi

\section{ABSTRACT}

Title: Reduction of COD Concentration from Batik Waste Water Treatment in Seeding and Acclimatization Process Using Microorganism Preservation Materials (MPMO)

Background: Batik is an Indonesian cultural heritage whose export value is increasing rapidly. This impact can increase the state's income significantly. On the other hand, it expands job opportunities for people to produce batik. However, large batik production increases the volume of waste. This problem can pollute the environment if the batik waste is not decomposed properly. Therefore, we propose a bioremediation method to decipher the
\end{abstract}


pollutant COD in batik waste. This research aims to measure the ability of MPMO in reducing COD in batik waste. The results of previous studies showed that Bacillus licheniformis has the ability to reduce COD in textile waste. Moreover, MPMO containing Bacillus Licheniformis bacteria also can decrease COD in the sugar industry WWTPs.

Method: This research was conducted on a laboratory scale with the sample pollutants from the batik production in Yogyakarta. We used a batch system for the seeding and acclimatization process in MPMO. During the seeding process, nutrients are used to grow microorganisms. The acclimatization process uses a \% $v / v$ mixture of batik waste and nutrients as a process of adapting microorganisms to waste. Parameters of the seeding and acclimatization were recorded during the process, such as COD, pH, MLSS, and MLVSS. For $C O D$, the parameter was taken every 0 hours on the influent and 24 hours on the effluent reactor.

Result: The values of CODinfluent, CODefluent, COD removal efficiency, initial $\mathrm{pH}$, final $\mathrm{pH}, \mathrm{MLSS}$, and MLVSS obtained during the acclimation process were respectively $1145-3084 \mathrm{mg} / \mathrm{L}, 354-1268 \mathrm{mg} / \mathrm{L}, 54-82 \%$, 6.43- 8.25, 7.33-8.32, 790.5-2356.5 mg / L, 0.454-1.657 mg / L.

Conclusion: The use of MPMO with Bacillus licheniformis bacteria can remove COD from batik waste in the acclimatization process by $82 \%$ with an average COD removal efficiency of $65 \%$.

Keywords: batik waste water; MPMO; Bacillus licheniformis; bioremediation

\section{PENDAHULUAN}

Batik merupakan kekayaan bangsa Indonesia yang telah ditetapkan UNESCO (United Nations Educational, Scientific, and Cultural Organization) sebagai Warisan Budaya dari Indonesia. ${ }^{1,2} \mathrm{Hal}$ tersebut mendorong peningkatan ekspor batik yang dapat menambah pendapatan negara dan meningkatkan lapangan kerja. ${ }^{3}$ Nilai Ekspor pada tahun 2011 sebesar $\mathrm{Rp}$ 43,96 triliun meningkat

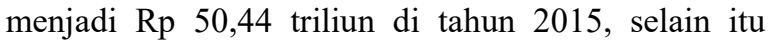
terjadi peningkatan unit usaha batik sebesar $14,7 \%$ selama kurun waktu lima tahun tersebut. ${ }^{4}$ Selain menghasilkan dampak positif berupa peningkatan pendapatan negara, namun industri kerajinan batik juga menghasilkan limbah pewarna kimia yang berpotensi mencemari lingkungan perairan dan juga berbahaya bagi manusia. ${ }^{5,6,7}$ Sekitar 10.000 jenis pewarna telah digunakan pada industri tekstil. ${ }^{8} \mathrm{Di}$ sektor batik, banyak pengusaha yang memperkerjakan pekerja rumahan untuk proses mencetak, menjahit, mewarnai, sampai proses pengemasan. ${ }^{9}$ Banyaknya industri batik dalam skala rumah tangga tersebut mengakibatkan potensi pencemaran lingkungan meningkat. Hal tersebut terjadi karena para pengrajin batik tidak memiliki instalasi pengolahan limbah sendiri sementara kapasitas unit instalasi limbah terpadu yang telah ada tidak dapat memenuhi keseluruhan volume limbah yang dihasilkan. ${ }^{10}$

Salah satu kota yang dikenal sebagai produsen batik di Indonesia dan dijadikan salah satu kota sentra pengrajin batik oleh UNESCO adalah kota Yogyakarta. ${ }^{11,12}$ Oleh karena itu, dalam penelitian ini digunakan limbah batik dari salah satu lokasi penghasil batik yang berada di Umbulharjo, Yogyakarta. Industri Kecil Menengah (IKM) selain memberikan dampak positif namun juga memberikan dampak negatif khususnya bagi pencemaran lingkungan. ${ }^{13}$ Limbah industri batik yang dibuang tanpa melalui pengolahan mencemari badan air dan sumur penduduk yang menjadi sumber air minum. ${ }^{15}$ Sedangkan limbah batik yang tergolong limbah pewarna mengandung berbagai bahan kimia berbahaya yang bersifat membahayakan bagi kehidupan manusia dan hewan, terutama pemanfaatan sumber air oleh manusia untuk aktivitas keseharian seperti mandi, memasak, minum dan mencuci. ${ }^{16,14}$

Limbah tekstil termasuk limbah yang mengandung banyak polutan seperti Biological Oxygen Demand (BOD), bahan kimia berbahaya, warna, Total Dissolved Solid (TDS), dan Total Suspended Solid (TSS). ${ }^{17,}{ }^{18}$ Berbagai metode telah diaplikasikan untuk pengolahan limbah pewarnaan yaitu dengan metode fisik-kimia seperti pengendapan menggunakan bahan kimia, ultrafiltrasi, adsorbsi menggunakan karbon, koagulasi-flokulasi, elektokimia, dan oksidasi menggunakan ozone. ${ }^{19,7}$ Namun, banyak dari metode-metode yang telah digunakan tidak efektif, menghasilkan by-products yang berbahaya, tidak dapat diaplikasikan dalam skala besar, atau membutuhkan biaya besar jika diaplikasikan untuk skala besar dan menghasilkan banyak lumpur. $^{20,14}$

Bioremediasi merupakan suatu proses pengolahan dengan memanfaatkan kemampuan mikroorganisme sehingga mampu menyisihkan polutan di lingkungan dengan menjadikan polutan organik sebagai sumber energi dan mendegradasinya menjadi bentuk yang bersifat tidak beracun. ${ }^{21,22}$ Pada penelitian sebelumnya, diketahui Material Preservasi Mikroorganisme (MPMO) adalah suatu sistem penyimpanan bakteri pengurai limbah cair organik berbentuk tablet dan memiliki kemampuan bertahan dalam jangka waktu (1-5) tahun. ${ }^{23}$ Selain itu MPMO yang diaplikasikan pada unit pengolahan biologis IPAL industri gula terbukti memiliki kemampuan dalam mereduksi kandungan polutan organik dalam limbah tersebut dengan parameter COD. ${ }^{24}$

Mikroorganisme yang dikembangbiakkan dan diimpregnasikan pada benthonit dalam bentuk MPMO adalah bakteri aerobic, yaitu Bacillus licheniformis. Bakteri Bacillus licheniformis dapat bertahan hidup dilingkungan yang keras dengan merubah bentuk 
menjadi spora dan dapat kembali dalam keadaan vegetatif dengan kondisi lingkungan yang sesuai. ${ }^{25}$ Selain itu, bakteri Licheniformis hasil isolasi dari tanah tercemar limbah tekstil memiliki kemampuan dalam meremoval COD, BOD5 TSS, dan TDS dengan hasil efisiensi penyisihan tertinggi pada parameter COD. $^{22}$ Penelitian ini bertujuan mengevaluasi penggunaan MPMO dengan Bacillus licheniformis dalam proses pengolahan limbah cair batik berdasarkan indikator penyisihan paramater COD.

\section{MATERI DAN METODE}

Lokasi penelitian terletak di Laboratorium Kualitas Air Pusat Penelitian Geoteknologi LIPI Bandung menggunakan limbah batik yang dihasilkan oleh pengrajin batik di kawasan Yogyakarta. Kegiatan penelitian laboratorium dilakukan selama bulan (Maret - Mei 2020). Metode yang dilakukan bersifat eksperimental berupa uji laboratorium menggunakan reaktor mini IPAL. Beberapa parameter yang telah dianalisa seperti $\mathrm{pH}$, COD, MLSS, dan MLVSS memiliki hubungan dengan masing-masing parameter. Kondisi satu parameter dapat berpengaruh terhadap parameter lainnya. Jumlah data yang digunakan berjumlah 19 data untuk masing-masing parameter yang diperoleh dari 4 data tahap seeding dan 15 data tahap aklimatisasi. Namun untuk beberapa parameter seperti MLSS, dan MLVSS menggunakan 9 data pada tahap aklimatisasi pada variasi Janis limbah 100\% limbah batik. Digunakan Interpolasi polynomial orde 2 untuk mengetahui kecenderungan dari nilai setiap parameter selama proses seeding dan aklimatisasi. Penelitian dilakukan menggunakan dua tahapan yaitu proses seeding dan aklimatisasi.

Proses pembenihan (seeding) merupakan tahap awal dari proses pengolahan secara biologis. Proses seeding dilakukan untuk menumbuhkan dan membentuk substrat populasi mikroorganisme dalam bioreactor. $^{26}$ Komposisi nutrient yang digunakan terdiri dari tapioka $(1,6 \mathrm{gr} / \mathrm{L})$, ammonium sulfat $(1,5$ $\mathrm{gr} / \mathrm{L})$, kalium di-hidro phospat (1 gr/L), calcium chloride $(1 \mathrm{gr} / \mathrm{L})$, magnesium chloride $(0,5 \mathrm{gr} / \mathrm{L})$, iron (II) chloride $(0,05 \mathrm{gr} / \mathrm{L})$, dan nutrien broth $(0,5 \mathrm{gr} / \mathrm{L})$. Konsentrasi tapioka yang digunakan disesuaikan dengan konsentrasi COD yang terkandung dalam limbah batik yang akan digunakan pada proses aklimatisasi. Pada proses seeding ini, volume nutrien dibuat sebanyak $8 \mathrm{~L}$, sehingga dibutuhkan tapioka (12,8 gr), ammonium sulfat (12 gr), kalium di-hidro phospat ( $8 \mathrm{gr})$, calcium chloride ( $8 \mathrm{gr})$, magnesium chloride (4 gr), iron (II) chloride ( 0,4 gr), dan nutrien broth (4 gr). Selama proses seeding dilakukan pengontrolan $\mathrm{pH}$ agar tetap dalam kondisi netral $(\mathrm{pH}$ =7). Pengontrolan $\mathrm{pH}$ dilakukan dengan penambahan HCL untuk menurunkan $\mathrm{pH}$ atau $\mathrm{NaOH}$ untuk menaikkan $\mathrm{pH}$. Pembuatan nutrien disesuaikan dengan konsentrasi limbah batik yang akan digunakan pada proses aklimatisasi yaitu $1145 \mathrm{mg} / \mathrm{L}$.
Proses aklimatisasi dilakukan agar mikroorganisme beradaptasi dengan lingkungan baru, termasuk jenis sumber makanan mikroorganisme. ${ }^{26}$ Proses tersebut merupakan salah satu tahapan adaptasi mikroorganisme terhadap komponen yang bersifat toksik yang terkandung dalam limbah batik sekaligus meningkatkan jumlah populasinya. ${ }^{27}$ Proses aklimatisasi Bacillus Licheniformis dan konsorsium mikroorganisme pada limbah batik dilakukan dengan pemberian limbah cair batik ke dalam nutrien secara kontinyu. Variasi pemberian limbah batik menggunakan perbandingan volume antara volume nutrient dengan volume limbah cair batik. Konsentrasi nutrien disesuaikan dengan konsentrasi COD pada limbah batik yang akan digunakan untuk proses aklimatisasi. Variasi perbandingan volume (nutrien: limbah batik) yang digunakan diantaranya 75\%:25\% (data ke-1), 50\%:50\% (data ke - 2), 25\%:75\% (data ke -3 ), dan $100 \%$ limbah batik (data ke -4 sampai dengan data ke- 15). Pembuatan variasi 75\%, 50\%, dan $25 \%$ nutrient buatan dengan volume $6 \mathrm{~L}$, $4 \mathrm{~L}$, dan 2 L dibutuhkan tapioka (9,6 gr; 6,4 gr; 3,2 gr), ammonium sulfat ( 9 gr; 6 gr; 3 gr), kalium di-hidro phospat ( 6 gr; 4 gr; 2 gr), calcium chloride (6 gr; 4 gr; 2 gr), magnesium chloride (3 gr; 2 gr; 1 gr), iron (II) chloride (0,3 gr; 0,2 gr; 0,1 gr), nutrien broth ( 3 gr; 2 gr; 1 gr). Pada 0 jam dan 24 jam dilakukan pengambilan sampel untuk mengetahui konsentrasi dari parameter COD. Sedangkan pada variasi $100 \%$ limbah batik juga dilakukan pengambilan sampel untuk parameter MLSS dan MLVSS.

Penelitian ini menggunakan reaktor batch aerobik, berbahan dasar akrilik dan berbentuk silinder dengan volume $8 \mathrm{~L}$ (Gambar 1). Pada proses aklimatisasi digunakan limbah cair dari proses pembuatan batik di kota Yogyakarta. Proses aklimatisasi dilakukan pada suhu ruangan $(\mathrm{T}=20-$ $25^{\circ} \mathrm{C}$ ) dan menggunakan aerasi/air diffuser berupa fine bubble aeration. Selama aklimatisasi dilakukan pengontrolan $\mathrm{pH}$ agar $\mathrm{pH}$ tetap dalam kondisi netral ( $\mathrm{pH}=7)$. Pengontrolan $\mathrm{pH}$ dilakukan dengan menambahkan $\mathrm{HCl}$ jika $\mathrm{pH}$ diatas 7 dan penambahan $\mathrm{NaOH}$ apabila $\mathrm{pH}$ dibawah 7. Hal tersebut dilakukan karena aktivitas enzim mikroba umumnya bekerja optimal pada rentang $\mathrm{pH}$ 6-8.

Limbah batik yang digunakan dalam penelitian ini diperoleh dari intake IPAL yang menampung limbah hasil proses pembuatan batik di Kota Yogyakarta. Karakterisasi terhadap limbah batik dilakukan sebelum dan sesudah dilakukan treatment. Parameter yang diamati pada studi ini yaitu $\mathrm{pH}, \mathrm{COD}$, MLSS, dan MLVSS. Keseluruhan parameter yang dianalisis menggunakan teknik standar pada Standard Methods untuk Examination of Water and Wastewater. $^{28}$

Penentuan nilai efisiensi penyisihan COD diperoleh dengan menggunakan konsentrasi COD pada influen dan efluen. Perhitungan nilai efisiensi penyisihan menggunakan rumus sebagai berikut ${ }^{29}$ : 
Efisiensi Penyisihan $(\%)=$

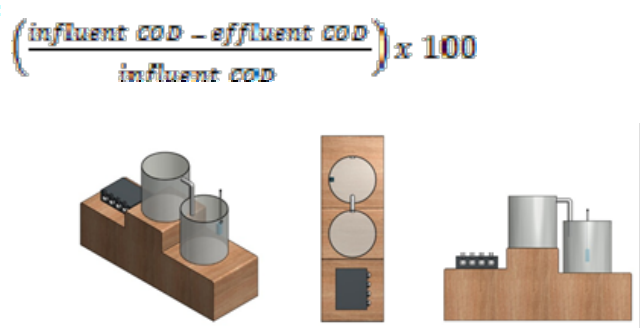

Gambar 1. Ilustrasi Reaktor Aerobik yang Digunakan Pada Proses Seeding dan Aklimatisasi

\section{HASIL DAN PEMBAHASAN}

Tujuan akhir dari penelitian ini yaitu untuk mengetahui efisiensi penyisihan COD dalam limbah batik oleh bakteri Bacillus licheniformis dalam bentuk MPMO dan kondisi setiap parameter yang mempengaruhi efisiensi penyisihan COD tersebut selama proses seeding dan aklimatisasi. Data-data beberapa parameter yang diperoleh selama proses seeding dan aklimatisasi ditampilkan pada Tabel 1.

Tabel 1. Data Parameter selama proses Seeding dan Aklimatisasi

\begin{tabular}{|c|c|c|c|c|c|c|c|c|c|}
\hline No & Jenis Limbah $(\% \mathrm{~V} / \mathrm{V})$ & $\begin{array}{l}\text { COD } \\
\text { Influen } \\
(\mathrm{mg} / \mathrm{L})\end{array}$ & $\begin{array}{l}\text { COD } \\
\text { Efluen } \\
(\mathrm{mg} / \mathrm{L})\end{array}$ & $\begin{array}{l}\text { Beban Organik } \\
\text { (kg COD/hari) }\end{array}$ & $\begin{array}{l}\text { Efisiensi } \\
\text { Penyisihan } \\
\text { COD (\%) }\end{array}$ & $\begin{array}{c}\mathrm{pH} \\
\text { Awal }\end{array}$ & $\begin{array}{c}\mathrm{pH} \\
\text { Akhir }\end{array}$ & $\begin{array}{l}\text { MLSS } \\
(\mathrm{mg} / \mathrm{L})\end{array}$ & $\begin{array}{c}\text { MLVSS } \\
(\mathrm{mg} / \mathrm{L})\end{array}$ \\
\hline \multicolumn{10}{|c|}{ Proses Seeding } \\
\hline 1 & $100 \%$ Nutrien Buatan & 663 & 395 & 0.005 & 40 & 4.09 & 6.21 & - & - \\
\hline 2 & $100 \%$ Nutrien Buatan & 2054 & 1912 & 0.016 & 7 & 6.37 & 6.54 & - & - \\
\hline 3 & $100 \%$ Nutrien Buatan & 2563 & 1607 & 0.021 & 37 & 6.31 & 6.74 & - & - \\
\hline 4 & $100 \%$ Nutrien Buatan & 2287 & 1524 & 0.018 & 33 & 6.51 & 7.06 & - & - \\
\hline \multicolumn{10}{|c|}{ Proses Aklimatisasi } \\
\hline 5 & $\begin{array}{l}\text { 75\% Nutrien Buatan, } \\
25 \% \text { Limbah Batik } \\
50 \% \text { Nutrien Buatan, }\end{array}$ & 1611 & 648 & 0.013 & 60 & 6.43 & 7.43 & - & - \\
\hline 6 & $\begin{array}{l}50 \% \text { Limbah Batik } \\
25 \% \text { Nutrien Buatan, }\end{array}$ & 3084 & 556 & 0.025 & 82 & 7.05 & 7.33 & - & - \\
\hline 7 & 75\% Limbah Batik & 3045 & 1268 & 0.024 & 58 & 7.26 & 7.99 & - & - \\
\hline 8 & 100\% Limbah Batik & 2434 & 937 & 0.019 & 61 & 7.91 & 7.63 & - & - \\
\hline 9 & 100\% Limbah Batik & 1145 & 532 & 0.009 & 54 & 7.23 & 8.11 & 2656 & 1.657 \\
\hline 10 & $100 \%$ Limbah Batik & 1145 & 462 & 0.009 & 60 & 8.2 & 8.3 & 2356.5 & 1.461 \\
\hline 11 & 100\% Limbah Batik & 1145 & 389 & 0.009 & 66 & 8.12 & 8.2 & - & - \\
\hline 12 & 100\% Limbah Batik & 1145 & 495 & 0.009 & 57 & 7.73 & 8.25 & 1986 & 1.2325 \\
\hline 13 & 100\% Limbah Batik & 1145 & 446 & 0.009 & 61 & 8.25 & 8.11 & 1308 & 0.779 \\
\hline 14 & $100 \%$ Limbah Batik & 1145 & 461 & 0.009 & 60 & 8.12 & 8.16 & 790.5 & 0.454 \\
\hline 15 & $100 \%$ Limbah Batik & 1145 & 371 & 0.009 & 68 & 8.25 & 8.26 & 1030.5 & 0.601 \\
\hline 16 & 100\% Limbah Batik & 1145 & 461 & 0.009 & 60 & 7.98 & 7.91 & 1777.5 & 1.1085 \\
\hline 17 & 100\% Limbah Batik & 1145 & 408 & 0.009 & 64 & 7.68 & 8.09 & 1152.5 & 0.7015 \\
\hline 18 & 100\% Limbah Batik & 1748 & 354 & 0.014 & 80 & 8.12 & 8.3 & 1555.5 & 0.963 \\
\hline 19 & $100 \%$ Limbah Batik & 1748 & 366 & 0.014 & 79 & 8.22 & 8.32 & 1544 & 0.9515 \\
\hline
\end{tabular}

Ket : Sumber data diolah dari hasil uji Laboratorium Kualitas Air Fakultas Teknik Sipil dan Lingkungan ITB, Laboratorium Kimia Puslit Geoteknologi

A. Nilai Efisiensi Penyisihan COD, Beban organik (Organic Loading Rate), MLSS, dan pH

Mixed Liquor Suspended Solid (MLSS) merupakan konsentrasi suspended solids dalam mixed liquor yang merupakan pecampuran antara raw atau settled wastewater dan activated sludge. ${ }^{30}$ MLSS juga mewakili jumlah total microbial biomass. ${ }^{31}$ Nilai MLSS pada tahap aklimatisasi dengan variasi perbandingan volume $100 \%$ limbah batik menunjukkan kecenderungan penurunan namun kembali meningkat di akhir tahap aklimatisasi. Pada Gambar 2 menunjukkan kenaikan nilai MLSS di akhir tahap aklimatisasi sejalan dengan kenaikan beban organik. Kenaikan beban organik dari 0,009 kg COD/hari hingga $0,014 \mathrm{~kg} /$ hari mengakibatkan peningkatan MLSS dari 790,5 $\mathrm{mg} / \mathrm{L}$ hingga 1555,5 $\mathrm{mg} / \mathrm{L}$. Nilai MLSS tertinggi pada tahap aklimatisasi sebesar $2.656 \mathrm{mg} / \mathrm{L}$, konsentrasi terendah 790,5 mg/L, dan rata-ratanya sebesar $1.616 \mathrm{mg} / \mathrm{L}$. 


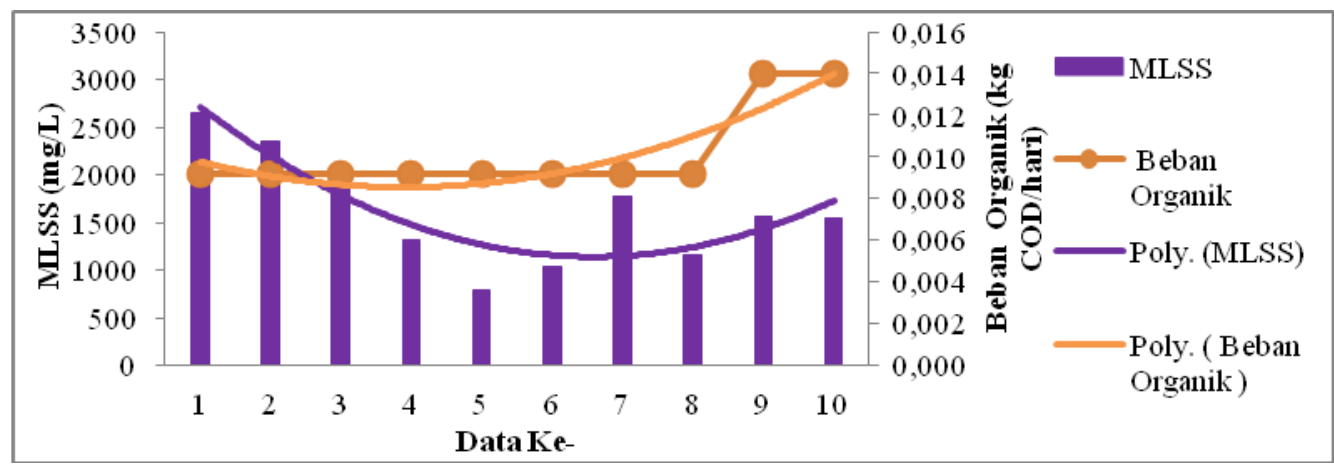

Gambar 2. Beban Organik (Organic Loading Rate) dan MLSS pada Proses Aklimatisasi Variasi Limbah 100\%

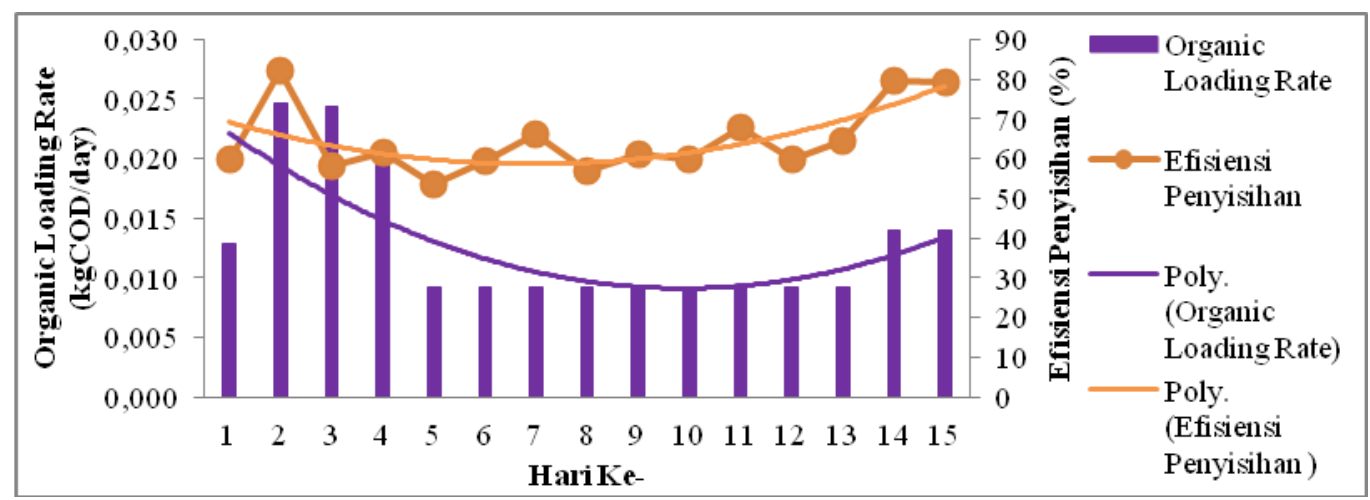

Gambar 3. Organic Loading Rate dan Efisiensi Penyisihan pada pada Proses Aklimatisasi

Peningkatan konsentrasi beban organik yang disertai peningkatan konsentrasi MLSS sesuai dengan hasil penelitian yang menyatakan bahwa MLSS yang menyatakan tingkat pemanfaatan substrat meningkat ketika terjadi peningkatan beban organik ${ }^{32}$. Nilai MLSS yang memadai untuk proses pengolahan air limbah dengan proses lumpur aktif yaitu berkisar antara $2.000-3.500 \mathrm{mg} / \mathrm{L} .{ }^{33}$ Sehingga berdasarkan nilai rata-rata tersebut dapat disimpulkan bahwa nilai MLSS belum memadai untuk pengolahan air limbah namun berdasarkan konsentrasi COD efluen selama proses seeding dan aklimatisasi menunjukkan adanya efisiensi penyisihan yang cukup signifikan. Nilai efisiensi penyisihan COD selama proses seeding yaitu $7 \%-40 \%$, sedangkan pada proses aklimatisasi yaitu $54 \%-82 \%$.

Selain dengan nilai MLSS, pada Gambar 3 menggambarkan kecenderungan peningkatan organic loading rate (OLR) berupa COD selama proses aklimatisasi yang juga diikuti dengan peningkatan efisiensi penyisihan COD. Peningkatan tersebut digambarkan dengan Interpolasi polynomial orde 2. Peningkatan efisiensi penyisihan COD tertinggi yaitu dari $60 \%$ menjadi $82 \%$ dengan peningkatan OLR sebesar $0,013 \mathrm{~kg}$ COD/day menjadi $0,025 \mathrm{~kg}$ $\mathrm{COD} /$ day. Kecenderungan peningkatan OLR yang diikuti dengan peningkatan Efisiensi Penyisihan terjadi pada pertengahan sampai dengan akhir proses aklimatisasi. Namun pada awal proses aklimatisasi dengan adanya peningkatan OLR selama 2 hari berturut-turut maka terjadi penurunan nilai Efisiensi Penyisihan dari $82 \%$ menjadi $58 \%$.

Peningkatan konsentrasi OLR dapat pula meningkatkan Efisiensi Penyisihan COD. ${ }^{32}$ Selain itu penurunan Efisiensi Penyisihan yang terjadi dapat diakibatkan karena tingginya OLR dapat menurunkan konsentrasi biomass dan meningkatkan akumulasi konsentrasi zat anorganik dalam reaktor sehingga mengakibatkan ketidakstabilan proses dalam reaktor. Hal tersebut sesuai dengan hasil penelitian yang menyebutkan bahwa tingginya OLR dapat menurunkan konsentrasi biomass dan meningkatkan akumulasi konsentrasi zat anorganik dalam reaktor sehingga dapat mengakibatkan ketidakstabilan proses dalam reaktor. ${ }^{34}$ Selain itu pada hasil penelitian lain juga menyebutkan bahwa peningkatan OLR dapat mengakibatkan terjadinya penurunan Efisiensi Penyisihan COD. ${ }^{32}$ Berdasarkan hasil tersebut dapat disimpulkan bahwa pada konsentrasi tertentu peningkatan OLR dapat meningkatkan efisiensi penyisihan COD namun hal sebaliknya dapat terjadi apabila dengan peningkatan OLR terjadi akumulasi zat anorganik dalam reaktor sehingga menganggu kestabilan proses biologis didalamnya.

Pada Gambar 4 menunjukan hasil proses seeding dan aklimatisasi yang dilakukan selama 19 hari menunjukkan hasil yang signifikan dalam mendegradasi COD. Efisiensi Penyisihan paling optimal terjadi pada hari kedua proses aklimatisasi dengan efisiensi penyisihan mencapai $82 \%$. Nilai efisiensi penyisihan berdasarkan grafik menunjukkan 
kecenderungan peningkatan. Kecenderungan peningkatan nilai efisiensi penyisihan disertai dengan kecenderungan penurunan konsentrasi COD pada efluen. Konsentrasi COD terkecil pada efluen terjadi pada proses aklimatisasi yaitu data ke 18 dengan konsentrasi sebesar $354 \mathrm{mg} / \mathrm{L}$.

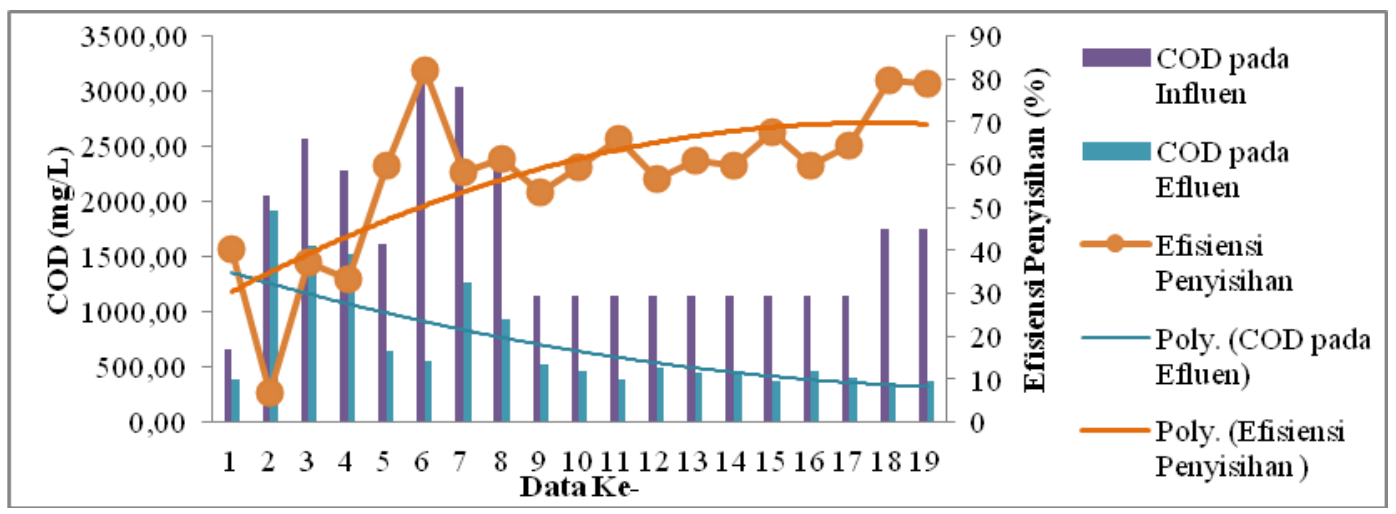

Gambar 4. Konsentrasi COD Influen dan Efluen Selama Proses Seeding dan Aklimatisasi

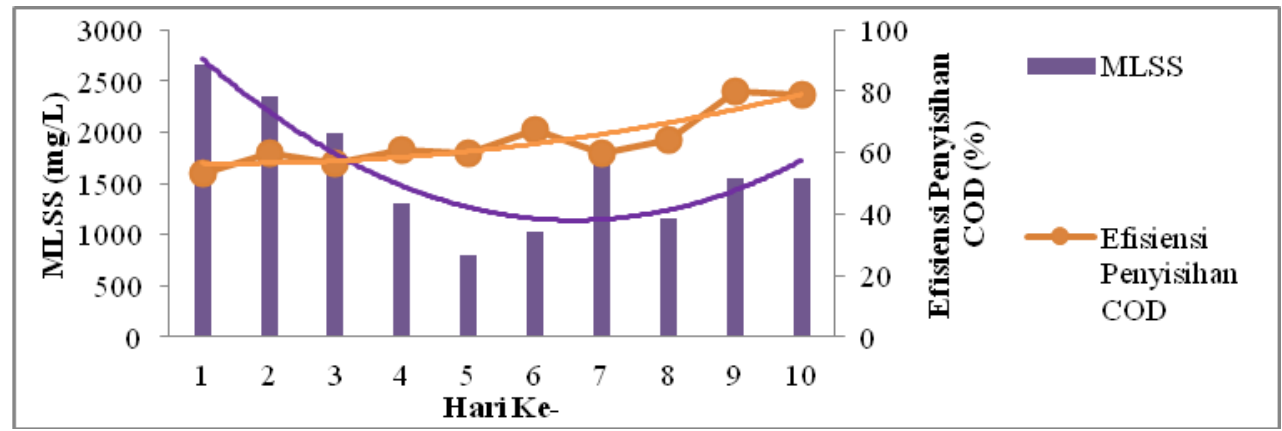

Gambar 5. MLSS dan Efisiensi Penyisihan COD dengan Variasi Volume Limbah Batik 100\%

Di dalam air limbah terdapat jenis zat organik yang tahan terhadap oksidasi secara biologis, akan tetapi dapat diuraikan dengan pereaksi yang bersifat oksidator kuat dalam suasana asam seperti kalium dikromat atau permanganat. ${ }^{35}$ Nilai COD dapat menunjukkan kandungan organik di dalam air yang mudah maupun yang tidak mudah diuraikan secara biologis (non-biodegradable) dan hasil penelitian menyebutkan bahwa pengolahan secara aerob juga dibutuhkan untuk menghilangkan senyawa toksik yang terbentuk pada proses anaerob (amina aromatik) menjadi metabolit non toksik. ${ }^{36}$. Efisiensi penyisihan optimum yang terjadi pada hari ke dua tahap aklimatisasi dapat disebabkan oleh aktifitas bakteri yang selama ini dalam kondisi "tidur" dalam material preservasi dibangunkan dan beradaptasi dengan lingkungan barunya. Kendati dari grafik terlihat Efisiensi Penyisihan mengalami penurunan setelah hari ke dua namun cenderung stabil pada harihari berikutnya dan mengalami peningkatan yang signifikan di akhir proses aklimatisasi yang nilai Efisiensi Penyisihannya mencapai $80 \%$. Oleh karena itu secara keseluruhan dapat terlihat bahwa efektifitas proses degradasi nilai COD menggunakan mikroorganisme dalam kondisi aerob cukup baik. Penurunan konsentrasi COD disebabkan terjadinya proses degradasi bahan organik yang dibutuhkan sebagai nutrisi atau makanan bagi bakteri. ${ }^{37}$ Dekomposisi bahan organik pada dasarnya melalui dua tahap yaitu bahan organik diuraikan menjadi bahan anorganik. Bahan anorganik yang tidak stabil mengalami oksidasi menjadi bahan anorganik yang stabil, misalnya ammonia mengalami oksidasi menjadi nitrit dan nitrat. ${ }^{38}$

Pada proses pengolahan limbah batik menggunakan MPMO secara kontinyu konsentrasi MLSS mengalami penurunan sampai dengan hari kelima namun kembali mengalami kenaikan di hari keenam meskipun tidak terjadi peningkatan konsentrasi yang signifikan. Penurunan konsentrasi MLSS terbesar pada hari kelima 39,6\% dibandingkan dengan konsentrasi MLSS pada hari keempat. Konsentrasi MLSS pada hari keempat sebesar 1308 $\mathrm{mg} / \mathrm{L}$, sedangkan pada hari kelima sebesar 790,5 $\mathrm{mg} / \mathrm{L}$. Selain itu nilai MLSS yang mewakili konsentrasi biomass mengalami kenaikan perlahan diakhir tahap aklimatisasi. Kondisi tersebut juga diikuti dengan kenaikan nilai Efisiensi Penyisihan parameter COD. Nilai MLSS tertinggi selama proses aklimatisasi terjadi pada data ke delapan belas sebesar $1555,5 \mathrm{mg} / \mathrm{L}$ menghasilkan nilai efisiensi penyisihan COD terbesar ke dua yaitu sebesar $80 \%$. 
Penurunan nilai MLSS yang terjadi pada tahap aklimatisasi dapat dikarenakan adanya proses penguraian mikroorganisme dalam lumpur yang terjadi selama tahap aklimatisasi. ${ }^{39}$. Terjadinya peningkatan konsentrasi MLSS pada akhir tahap aklimatisasi dan disertai peningkatan nilai efisiensi penyisihan. Hal tersebut dikarenakan bahwa peningkatan konsentrasi biomass dapat meningkatkan efisiensi penyisihan COD. ${ }^{40 ; 41}$

Pada Gambar 6 terlihat fluktuasi nilai pH pada limbah batik dimana pada proses seeding dan aklimatisasi terlihat proses adaptasi mikroorganisme terhadap limbah mempengaruhi nilai $\mathrm{pH}$ sehingga naik dan turunnya nilai $\mathrm{pH}$ belum stabil. Kestabilan nilai $\mathrm{pH}$ mulai terlihat pada hari ke 17 adapun $\mathrm{pH}$ yang ada tidak mengalami perubahan secara signifikan. Pengukuran nilai $\mathrm{pH}$ awal limbah sintetis berupa nutrien murni maupun kombinasi nutrien dengan limbah batik menunjukkan kondisi yang cenderung asam. Namun terjadi peningkatan nilai $\mathrm{pH}$ menjadi cenderung basa setelah waktu tinggal selama 24 jam dalam reaktor selama proses seeding dan aklimatisasi.

Kestabilan nilai $\mathrm{pH}$ yang terjadi diduga karena sedikitnya zat-zat organik yang diuraikan oleh mikroorganisme. Sesuai dengan pernyataan hasil penelitian yang menyebutkan semakin sedikit zat-zat organik diuraikan oleh mikroorganisme maka $\mathrm{pH}$ yang dihasilkan semakin basa dan jika semakin banyak zat-zat organik yang diuraikan maka semakin asam $\mathrm{pH}$ yang dihasilkan. ${ }^{42}$ Jadi sedikitnya zat-zat organik yang diuraikan pada bak aerasi maka menyebabkan terjadinya peningkatan nilai $\mathrm{pH}$. Dilihat dari penurunan kadar COD didapatkan peningkatan nilai $\mathrm{pH}$ antara sebelum dan sesudah pengolahan.

Salah satu kemungkinan penyebab meningkatnya nilai $\mathrm{pH}$ dikarenakan keberadaan senyawa organik khususnya senyawa yang mengandung gugus amina dalam limbah sintetis. Senyawa tersebut terurai menjadi ammonia sehingga menyebabkan peningkatan $\mathrm{pH}$. Peningkatan $\mathrm{pH}$ menjadi basa dapat dipengaruhi oleh proses degradasi senyawa yang mengandung gugus amina seperti protein dan asam amino. ${ }^{43}$ Selain itu kondisi awal limbah batik yang digunakan dalam proses aklimatisasi yang cenderung bersifat basa dapat menjadi salah satu penyebab peningkatan nilai $\mathrm{pH}$ selama proses aklimatisasi dibandingkan dengan nilai $\mathrm{pH}$ pada proses seeding. Hal tersebut sesuai dengan dua hasil penelitian yang menyebutkan bahwa limbah batik pada umumya bersifat basa dan mengandung polutan organik yang tinggi hasil dari proses pembatikan. 44,45

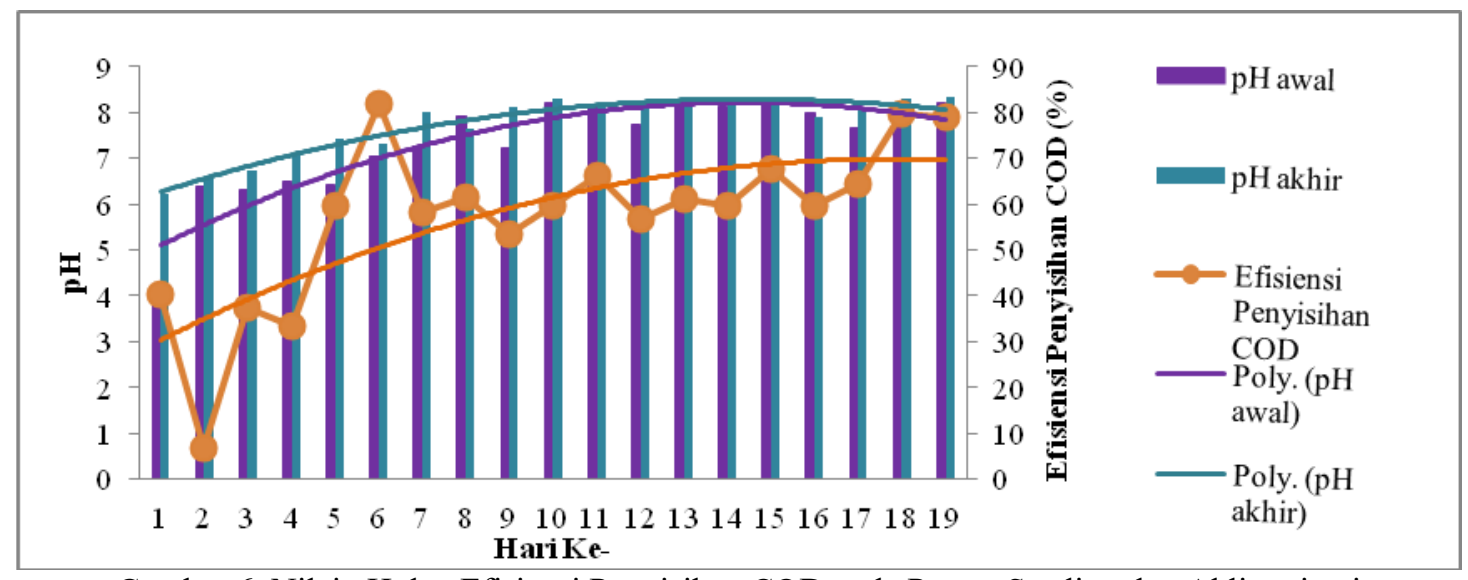

Gambar 6. Nilai pH dan Efisiensi Penyisihan COD pada Proses Seeding dan Aklimatisasi

Peningkatan nilai $\mathrm{pH}$ disertai dengan peningkatan nilai Efisiensi Penyisihan COD. Hal tersebut menunjukkan bahwa proses degradasi COD dapat berlangsung dengan baik. Hasil peneltian lain juga menyebutkan bahwa peningkatan $\mathrm{pH}$ juga disertai dengan peningkatan Efisiensi Penyisihan COD, hal tersebut dikarenakan $\mathrm{pH}$ tinggi dapat memperbanyak bagian sel aktif yang mampu meningkatkan proses pengikatan and bioflokulasi. ${ }^{46}$

\section{SIMPULAN}

Pengolahan limbah batik menggunakan MPMO dengan bakteri Bacillus licheniformis pada proses aklimatisasi terbukti dapat menurunkan konsentrasi
COD yang terkandung dalam limbah. Tinggi rendahnya nilai efisiensi penyisihan COD pada proses aklimatisasi dipengaruhi oleh nilai $\mathrm{pH}$, dimana peningkatan nilai $\mathrm{pH}$ disertai dengan peningkatan nilai efisiensi penyisihan COD. Selain itu peningkatan nilai MLSS dan Organic Loading Rate (OLR) juga disertai dengan meningkatnnya nilai efisiensi penyisihan COD, namun pada awal proses aklimatisasi dengan adanya peningkatan OLR dari dari $0,013 \mathrm{kgCOD} /$ day menjadi $0,024-0,025 \mathrm{~kg}$ $\mathrm{COD} /$ day menyebabkan penurunan nilai efisiensi penyisihan COD. Nilai tersebut belum memenuhi baku mutu air limbah untuk kegiatan Industri Batik berdasarkan Perda DIY No 7 Tahun 2016 tentang 
baku mutu air limbah, oleh karena itu dibutuhkan pengolahan lebih lanjut dengan sistem kontinyu.

\section{DAFTAR PUSTAKA}

1. Kusumawati N, Wijiastuti A, Rahmadyanti EN, Kusumawati A, Wijiastuti ER. Operating Conditions Optimization on Indonesian Batik : Dyes Wastewater Treatment by Fenton Oxidation and Separation Using Ultrafiltration Membrane. Journal of Environmental Science \& Engineering. May2012; Vol. 1 Issue 5A, p672.

2. Sutisnaa EW, Mamat R, Dui YR, Riri M, Khairurrijala, and Mikrajuddin A. Batik Wastewater Treatment Using TiO2 Nanoparticles Coated on the Surface of Plastic Sheet. Procedia Engineering. 2017; 170, 78 - 83 https://doi.org/10.1016/j.proeng.2017.03.015

3. Handayani W, Arianti IRH, A Ign K. Penetapan Skala Industri Batik Rumahan Menurut Kriteria Lokal : Studi di Desa Jarum, Kabupaten Klaten. $2017 . \quad$ Manajemen IKM. https://doi.org/10.29244/mikm.12.1.25-34

4. Rahayu DP. Peta Politik Industri Batik Yogyakarta dan Dampaknya dalam Sistem Perburuhan Batik di Yogyakarta. Jurnal Kajian Ruang Sosial-Budaya. 2019; Vol. 3, No. 1 Hal.30-45.

5. Kitture R, Soumya JK, Ruchika KG, S.N. Kale RK, S.J. Koppikar, R. Kaul G, S.N. Kale. Catalyst efficiency, photostability and reusability study of $\mathrm{ZnO}$ nanoparticles in visible light for dye degradation. J. Phys. Chem. Solids. 2011; 72 60 66. https://doi.org/10.1016/j.jpcs.2010.10.090

6. Sonta MA, Gunawan, Antari AA. Strategi Adaptasi Ekologi Masyarakat Dalam Menghadapi Pencemaran Limbah Produksi Batik (Studi Etnoekologi di Daerah Aliran Sungai Setu, Kelurahan Jenggot, Kecamatan Pekalongan Selatan, Kota Pekalongan). Solidarity. 2017; 6 (2).

7. Mukimin A, Hanny V, Nur Z, Agus P, Kukuh AW. Performance of BioequalizationElectrocatalytic Integrated Method for Pollutants Removal of Hand-drawn Batik Wastewater. Journal of Water Process Engineering. 2018; 21, 77-83.

https://doi.org/10.1016/j.jwpe.2017.12.004

8. Christiany A, Suprihatin, Indrasti NS. Potensi teknis-ekonomis daur ulang efluen air limbah industri tekstil menggunakan aplikasi arang aktif. JPSL. $\quad 2019 ; \quad 9(2)$ : 229-240. https://doi.org/10.29244/jps1.9.2.229-240

9. International Labour Office. Penelitian tentang Praktik Pengusaha dalam Mempekerjakan Pekerja Rumahan di Provinsi Jawa Barat dan Jawa Tengah. ILO-Apindo Intercafe, Jakarta. 2015.

10. Sari DP, Sri H, Dyah IR, Tri SW. Pengukuran Tingkat Eko-efisiensi Menggunakan Life Cycle Assessment untuk Menciptakan Sustainable
Production di Industri Kecil Menengah Batik. Jurnal Teknik Industri. 2012; Vol. 14, No. 2. https://doi.org/10.9744/jti.14.2.137-144

11. Sardjono A, Brian AP, Desrezka GL. Pelaksanaan Perlindungan Hukum Merek untuk Pengusaha UKM Batik di Pekalongan, Solo dan Yogyakarta. Jurnal Hukum dan Pembangunan. OktoberDesember 2013; Tahun ke-43 No.4. https://doi.org/10.21143/jhp.vol44.no4.32

12. Kemenperin. Karya Indonesia Batik Nusantara. 2013.

13. Sulaksono A, Hefni E, Budi K. Kajian Beban Pencemaran Limbah Cair Industri Kecil Menengah (IKM) Batik Klaster Trusmi Kabupaten Cirebon. Jurnal Pengelolaan Sumberdaya Alam dan Lingkungan. Juli 2015;

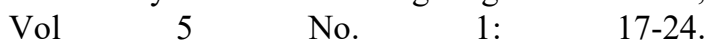
https://doi.org/10.19081/jps1.2015.5.2.17

14. Katheresan V, Jibrail K, Sie YL. Efficiency of various recent wastewater dye removal methods: A review. Journal of Environmental Chemical Engineering. 2018; 6: 4676-4697. https://doi.org/10.1016/j.jece.2018.06.060

15. Maria R., Nyoman S, Dadan S, Dyah M. Pengaruh Limbah Cair Industri Batik Terhadap Kualitas Air Tanah Dangkal di Daerah Laweyan Surakarta. Prosiding Pemaparan Hasil Penelitian Pusat Geoteknologi LIPI. 2014; ISBN: 978-9798636-23-3.

16. Zongping W, Kai H, Miaomiao X, Zizheng L. Textile Dyeing Wastewater Treatment. INTECH Open Access Publisher, Rijeka. 2011.

17. Liu L, Juan Z, Yi T, Yucheng J, Mancheng H, Shuni L, Quanguo Z. Rapid decolorization of anthraquinone and triphenylmethane dye using chloroperoxidase: Catalytic mechanism, analysis of products and degradation route. Chemical Engineering Journal. May 2014; 244(15):9-18. https://doi.org/10.1016/j.cej.2014.01.063

18. Ganiyu SA, Oluwole OA, Saheed AL, Kazeem OS, Idris AB, Muhammad Q, Khalid A. Borondoped activated carbon as efficient and selective adsorbent for ultra-deep desulfurization of 4,6dimethyldibenzothiophene. Chemical Engineering Journal Volume. 1 August 2017; 321: 651. https://doi.org/10.1016/j.cej.2017.03.132

19. V.K. Gupta, Suhas. Application of low-cost adsorbents for dye removal-a review. J. Environ. Manage. 2009;90 (8): 2313-42. https://doi.org/10.1016/j.jenvman.2008.11.017

20. Wan FK, Li NH, Soon AO, Yee SW, Nik AY, Fahmi R. Decolorization and Mineralization of Batik Wastewater through Solar Photocatalytic Process. Sains Malaysiana. 2015: 44(4): 607-12. https://doi.org/10.17576/jsm-2015-4404-16

21. Endeshaw A, Birhanu G, Zerihun T, Misganaw W.Application of microorganisms in bioremediation-review J. Environ. Microb. 2017; 1(1): 2-9. 
22. Ajao AT, Sulugambari BZ, Awe S. Bioremediation of wastewaters from local textile industries in Ilorin, Nigeria. Sciences, Kwara State University, Malete, Nigeria.

23. Sembiring H, Sumarnadi ET, Effendi, Gurharyanto. Pelletisasi Bentonit Sebagai Preservasi Bakteri Pengurai Limbah Organik Cair : Rekayasa dan Prototip, Prosiding Pemaparan Hasil Penelitian Pusat Penelitian Geoteknologi LIPI. 2012; ISBN 978-979-8636-19-6, Bandung.

24. Agustinus ETS, Happy S, Effendi. Aplikasi Material Preservasi Mikroorganisme (MPMO) dalam Pemrosesan Limbah Cair Organik Pada Instalasi Pengolahan Air Limbah. Riset Geologi Pertambangan. Juni 2014; 24(1):65-76. https://doi.org/10.14203/risetgeotam2014.v24.82

25. Veith B, Herzberg, Steckel S, Feesche J, Maurer $\mathrm{KH}$, Ehrenreich P, Baumer S, Henne A, Liesegang H, Merkl R, Ehrenreich A, Gottschalk $\mathrm{G}$. The complete genome sequence of Bacillus licheniformis DSM13, an organism with great industrial potential. J Mol. Microbiol. Biotechnol. 2004,7(4):204-

211.https://doi.org/10.1159/000079829

26. Kahar A, Eko H, Lukman M, Budi, Nining W, Ika, Mey C. The Study of Seeding and Acclimatization from Leachate Treatment in Anaerobic Bioreactor. ARPN Journal of Engineering and Applied Sciences. April 2017:12(8).

27. Hubbe MA, JR Metts, D Hermosilla, MA Blanco, L Yerushalmi, F Haghighat, P Lindholm L, Z. Khodaparast, M Kamali, A Elliott. Wastewater treatment and reclamation: a review of pulp and paper industry practices and opportunities. BioResources.

2016;11. https://doi.org/10.15376/biores.11.3.Hubbe

28. APHA. Standard Methods for the Examination of Water and Wastewater, American Public Health Association, 2lst ed. Washington, DC. 2005.

29. N. Seetha, Renu B, Pramod K. Effect of organic shock loads on a two-stage activated sludgebiofilm reactor. Bioresource Technology. 2010; 101:

3060-66. https://doi.org/10.1016/j.biortech.2009.12.055

30. Wateronline. 2020

https://www.wateronline.com/doc/mixed-liquorsuspended-solids-in-wastewater-0002, Accessed 18.08.20.

31. Cla'udia FG, Sandra S, Joa o GC. Galinha CF, Sanches S, Crespo JG. Membrane bioreactors. Fundamental Modelling of Membrane Systems. 2018: 209-49. https://doi.org/10.1016/B978-012-813483-2.00006-X

32. Kanimozhi R, Vasudevan N. Effect of organic loading rate on the performance of aerobic SBR treating anaerobically digested distillery wastewater. Clean Technologies and
Environmental Policy. 2013;16(3):46776. doi:10.1007/s10098-013-0639-x

33. Suryadiputra INN. Pengolahan Air Limbah dengan Metoda Biologi. Strengthening Program : Rancang Bangun IPAL. Bandung. 1994.

34. Chelliapan S, Wilby T, Yuzir A, Sallis PJ. Influence of organic loading on the performance and microbial community structure of an anaerobic stage reactor treating pharmaceutical wastewater. Desalination. 2011; 271:257-64. https://doi.org/10.1016/j.desal.2010.12.045

35. Eskani, Istianah N, Carlo, Evone dan Sulaeman. Efektivitas Pengolahan Air Limbah Batik dengan Cara Kimia dan Biologi. 2005.

36. Balapure, Kshama \& Jain, Kunal \& Bhatt, Nikhil \& Madamwar, Datta. Exploring bioremediation strategies to enhance the mineralization of textile industrial wastewater through sequential anaerobic-microaerophilic process. International Biodeterioration \& Biodegradation. 2016;106: 97-105. 10.1016/j.ibiod.2015.10.008. https://doi.org/10.1016/j.ibiod.2015.10.008

37. Indriyati. Proses Pembenihan (Seeding) dan Aklimatisasi pada Reaktor Tipe Fixed Bed, J. Tek.Ling.P3TL-BPPT. 2003;2:54-60.

38. Effendi H. Telaah Kualitas Air : Bagi Pengelolaan Sumber Daya dan Lingkungan Perairan. Penerbit : Kanisius. Yogyakarta. 2003.

39. Bornare J, Kalyanraman V, Sonde RR. Application of Anaerobic Membrane Bioreactor (AnMBR) for Low-Strength Wastewater Treatment and Energy Generation. Industrial Wastewater Treatment, Recycling and Reuse. 2014: 399-434. doi:10.1016/b978-0-08-0999685.00010-6

40. Kim M, Guerra P, Theocharides M, Barclay K, Smyth SA, Alaee M. Parameters affecting the occurrence and removal of polybrominated diphenyl ethers in twenty Canadian wastewater treatment plants. Water Research. 2013;47(7): 2213.

https://doi.org/10.1016/j.watres.2013.01.031

41. Dong W, Min J, Can W. Degradation of Organic Pollutans and Characteristics of Activated Sludge in an Anaerobic/Anoxic/Oxic Reactor Treating Chemical Industrial Wastewater. Brazilian Journal of Chemical Engineering. 2014;31(03):703

13. https://doi.org/10.1590/01046632.20140313s00002748

42. Sastrawijaya AT. Pencemaran Lingkungan. Rineka Cipta, Jakarta. 2000.

43. Nilesh S, Anil G. Isolation, characterization and identification of extracellular enzyme producer Bacillus licheniformis from municipal wastewater and evaluation of their biodegradability. Biotechnology Research and Innovation. 2018; 2: 37-44. https://doi.org/10.1016/j.biori.2018.03.001 
44. Indrayani L, Nur R. Nilai Parameter Kadar Pencemar sebagai Penentu Tingkat Efektivitas Tahapan Pengolahan Limbah Cair Industri Batik. Jurnal Rekayasa Proses Research article. 2018;12(1):

41-50. https://doi.org/10.22146/jrekpros.35754

45. Apriyani N. Industri Batik: Kandungan Limbah Cair dan Metode Pengolahannya. Media Ilmiah Teknik Lingkungan. Februari 2018;3(1): Article
Review21-29.

https://doi.org/10.33084/mitl.v3i1.640

46. Gh Ghanizadeh, R Sarrafpour. The Effects of Temperature and $\mathrm{PH}$ on Settlability of Activated Sludge Flocs. Iranian J. Publ. Health. 2001;30(34):139-42.

cc) (i) (O) 2022. This open-access article is distributed under the terms and conditions of the Creative Commons Attribution-ShareAlike 4.0 International License. 